\title{
Gender Differences in the Perceptions of Entrepreneurship Hindrances: A Case of Vocational Education Students in Zimbabwe
}

\author{
Patient Rambe, Takawira Munyaradzi Ndofirepi \\ Central University of Technology, Bloemfontein, South Africa \\ prambe@cut.ac.za, takandofirepi@gmail.com
}

\begin{abstract}
Despite the compelling evidence on the capacity of gender biases rooted in subjective beliefs and assumptions to shape recognition and evaluation of business opportunities, there is limited research on whether females and males in resilient, economically troubled economies such as Zimbabwe conceive entrepreneurial constraints differently or in similar ways. In view of literature that highlights some marked gender variations in perceived feasibility and desirability of participating in entrepreneurial ventures, the current study explored whether femalestudents at Zimbabwean vocational education institutions would be more inclined to perceive entrepreneurial barriers differently than their male counterparts. A total of 365 students identified through simple random sampling were invited to participate in the study. On completion of the survey, 160 questionnaires were successfully completed, presenting a response rate of $43.8 \%$.The findings reveal that there were no significant differences between male and female students in their perceptions of entrepreneurship support, regulatory and socio-cultural barriers. However, males had stronger perceptions of financial barriers while females had stronger perceptions of personal barriers. The implication of these findings is that the Government of Zimbabwe should institute and implement more gender parity-based measures to ensure prospective entrepreneurs' transformative reflection on venture creation, and more inclusive access to and participation in entrepreneurial activities.
\end{abstract}

Keywords: Gender differences, entrepreneurship barriers, students, Zimbabwe

\section{Introduction}

While the contribution of gender parity to entrepreneurship is conceived to be critical to the advancement of entrepreneurship, hitherto job creation, economic growth and innovation in developing economies (Daim, Dabic, \& Bayraktaroglu, 2016; United Nations Development Programme African Human Development Report, 2016), gender gaps still persist in entrepreneurial activity (Rubio-Bañón \& Esteban-Lloret, 2016) in Africa. Rubio-Bañón and Esteban-Lloret (2016) are concerned that although the female and male entrepreneurship rates vary across countries due the influence of different roles and stereotypes on entrepreneurial behaviour, feminine entrepreneurship tends to be slower than masculine entrepreneurship. The South African entrepreneurial experience also exhibits persistent gender disparities in engagement in total entrepreneurship activity. Herrington et al. (2010) reports that South African men are 1.5 times more likely than women to be involved in early-stage entrepreneurial activity. The same entrepreneurial gender gaps are replicated internationally. Worldwide, notwithstanding the importance of their contribution in terms of entrepreneurship variety, the numbers of female entrepreneurs were lower than those of male entrepreneurs in almost every country especially in terms of Total Entrepreneurial Activity, except for Ghana, Costa Rica, and Australia (Kelley et al., 2010; Daim et al., 2016).

Understanding the relationship between gender and entrepreneurship activity is critical particularly in view of the inclusive research in this domain. Elam (2008) argue that an analysis of changes in predicted probabilities of nascent entrepreneurship across countries by gender and perceptions reflect similar patterns found among the general population. Elam (2008) elaborates that men were found to be more optimistic, confident and to possess social capital conducive to engage in nascent entrepreneurship than women in most countries. More so, an examination of Empirical Bayes predicted probabilities of nascent entrepreneurship across gender, perceptions and countries indicated that the gender gap in nascent entrepreneurship was actually more pronounced among those individuals with favourable perceptions of business start-up than those without. In other words, men and women who feared failure and stated a lack of start-up skills did not expect to see opportunities for business start-upshared similar possibilities of nascent entrepreneurship than their more confident optimist counterparts (Elam, 2008). While this study demonstrates how gender predicts entrepreneurial activity, other studies demonstrated gender variations in the perceived desirability of entrepreneurship activity across countries. For instance, Daim et al. (2016) explores how perceived feasibility 
and desirability impacted entrepreneurial behavior of students of different gender in 10 countries. Perceived desirability differences between genders per country showed that with regard to levels of difficulty associated with entrepreneurialactivities, there were statistically significant differences between genders in Croatia, whereas there were no statistically significant differences between gendersin Austria, France, Israel, Lithuania, Poland, Slovenia, India, and the rest of the world.

More so, the perception that men make better entrepreneurs than women might further account for the gender gap in entrepreneurship which shows no signs of shrinking, and has important implications for policymakers' efforts to close it (Shane, 2015). Using three randomized experiments (two in the United States and one the United Kingdom) Thébaud (2015) empirically tested the theoretical argument that widely shared cultural beliefs about men's and women's abilities in entrepreneurship (i.e., "gender status beliefs") systematically influence the social interactions during which an innovative entrepreneur seeks support from potential stakeholders for his or her new organisation. The studies, which manipulated the gender of the entrepreneur and the innovativeness of the business plan, consistently revealed that gender status beliefs disadvantage typical women entrepreneurs vis-à-vis their male counterparts. However, innovation in a business model has a stronger and more positive impact on ratings of women's entrepreneurial ability and overall support for their business ideas than it does for men's. In view of the importance of aligning entrepreneurial ventures to investors' preferences during early stages of business start-up, Brooks, Huang, Kearney, and Murray (2014) conducted experiments which involved participants watching videos of business start-up pitches during a business plan competition. The researchers randomly assigned voices of different gender to narrate otherwise identicalpitches. In another experiment, participants watched a single video in which the entrepreneur's gender was randomly assigned. Their findings suggest that across the different settings (three entrepreneurial pitch competitions in the United States) and two controlled experiments, investors preferred entrepreneurial pitches presented by male entrepreneurs compared to pitches presented by female entrepreneurs, even when the content of the pitches were the same. This result was moderated by physical attractiveness and attractive males were considered particularly persuasive whereas the physical attractiveness of female entrepreneurs did not matter.In a study that examined technology licensing officers' preferences of academic inventors' spinoff companies, Shane, Dolmans, Jankowski, Reymen and Romme (2015) found that technology licensing officers were significantly more likely to dissuade the inventor from starting a company to exploit anotherwise identicalventure by anotherwise identicalinventor if the inventor were female rather than male.

In view of the reality that increasing the number of female entrepreneurs implies heightened entrepreneurship variety in economy (Verheul et al., 2004; Daim et al., 2016) and that the possession of positive entrepreneurial beliefs and values (e.g. value opportunity recognition, strong self-efficacy) shapes perceived entrepreneurial capabilities (see Ajzen, 2006; Farrington, Gray and Sharp, 2012), there is scope to examine the influence of gender on perceptions of entrepreneurship barriers especially in resilient, economically depressed economies like that of Zimbabwe. While the growing body of literature that examined the Zimbabwean entrepreneurial context focuses on the entrepreneurial challenges facing the general population (Chitsike, 2000; Nani, 2011; Zindiye, Chiliya \& Masocha, 2012; Nyamanzwa, Mapetere, Mavhiki \& Dzingirai, 2012 Manuere et al., 2013), these studies tend to ignore the effect of gender on the perception of entrepreneurial barriers amongst pipeline entrepreneurs (e.g. university students), the research gap that this study attempts to close.The complexity of addressing the influence of gender perceptions on entrepreneurial barriersarises from the different domains in which female and male-led enterprises are often located in the economy. Male entrepreneurs tend to pursue ventures across a broad spectrum of industries, whereas female entrepreneurs predominantly pursue ventures that focus on female consumers such as fashion, cosmetics, and cooking (Brooks et al., 2014) and the Zimbabwean entrepreneurs are no exception. The uniqueness of the Zimbabwean entrepreneurship scenario arises from a combination of factors: a cash-strapped national government which seems to recognise entrepreneurship but struggles to productively fund emerging entrepreneurs (Ndofirepi, 2016), prevalence of vendor graduates which conjures images of the paucity of the entrepreneurial opportunities (Rambe, Ndofirepi and Dzansi, 2015), the general underrepresentation of women in innovation driven entrepreneurship and the prevalence of informal, low capital intensive businesses, which render low economic returns (Rambe and Ndofirepi, In Press).

To further our understanding on the gender-entrepreneurial barriers relationship, this study sought to 
establish whether the female students at a Zimbabwean Vocational Education institution perceived entrepreneurship impediments differently when compared to their male counterparts. The research, therefore, addressed the following research questions;

Do female students have a stronger perception of entrepreneurship support barriers than males?

Do female students have a stronger perception of regulatory barriers to entrepreneurship than males?

Do female students have a stronger perception of personal barriers to entrepreneurship than males?

Do female students have a stronger perception of financial barriers to entrepreneurship than males?

Do female students have a stronger perception of social cultural barriers to entrepreneurs than males?

The rest of the paper is structured as follows: Firstly, the extant literature on the relationship between gender, economic development and entrepreneurship is reviewed. This is followed by an outline of the research methods and processes applied in the study. Thereafter, the findings are then discussed. Lastly, implications, limitations and recommendations for further studies are offered.

Theorisation of Perceptions of Entrepreneurial Barriers: Our study on gendered perceptions of entrepreneurial barriers is informed by two entrepreneurial intention models, Shapero and Sokol (1982) entrepreneurial event model and David Harper's (2003) theory of entrepreneurial discovery. Shapero's model suggests that entrepreneurial intentions are directly shaped by perceived feasibility, perceived desirability of entrepreneurial activity and propensity to act (Shapero and Sokol, 1982; Dabic et al., 2012). Perceived feasibility is tied to belief in individual capacity and capability to influence desirable behavioural outcomes, that is, entrepreneurial behaviour. This concept closely approximates perceived behavioural control concept of the theory of planned behavior. Perceived desirability closely relates to one predisposition to act in a particular way. The perceived desirability can be aligned tothe propensity to act (Fitzsimmons and Douglas, 2011; Dabic et al., 2012). The concepts perceived feasibility, perceived desirability of entrepreneurial activity and propensity to act are invariably shaped by the prevailing entrepreneurial climate including the associated social cultural norms, financial, institutional and intellectual challenges that prevail in the social environment.

Haper's (2003) theory of entrepreneurial discovery focuses on individual values, in particular that individuals (of particular gender) with a strong sense of control and self-efficacy are the most likely to be alert to entrepreneurial opportunities (cited in Elam, 2008). The theory emphasises the presence of a sense of personal agency as a primary factor that drives an individual'swillingness to engage in entrepreneurship (O'Driscoll and Rizzo, 2015). This implies that individuals with high sense of control and self-efficacy may conceive ideal business opportunities and potential economic gains in complex, troubled economic situations whereas those with lower sense of control and limited self-efficacy may perceive economic challenges exclusively. This is particular so, given that risk taking, one of the key elements of the entrepreneurial process, is associated with a willingness to commit more resources to projects where the cost of failure may be high (Madichie, Hinson \& Ibrahim, 2013). Harper (2003, p. 14) observes that this personal agency "comprises two cognitive elements- beliefs in the locus of control (or contingency expectations) and beliefs in self-efficacy (or competency expectations)." This implies that entrepreneurial discovery is a consequence of a combination of ideal contextual influences that support entrepreneurial propensity, self-beliefsand personal competencies to effect changes that bring entrepreneurial results. For a potential entrepreneur with low selfefficacy, therefore, the prevalence of unconducive situational conditions may serve as barriers to his/her pursuit of entrepreneurship discovery.

At the macro level, the entrepreneurial discovery theory conceives freedom to act as a key value driving the rates of alertness and entrepreneurship activity in a given society (Harper, 2003, Elam, 2008). Harper examines how freedom as an institutional value shapes the constitutional, legal, economic, social and political rules of the game that affect people's perceived causal capabilities (Harper, 2003; Elam, 2008) with regard to entrepreneurship. The reasons for fewer female entrepreneurs worldwide are unequal access to finance, some legal restrictions and discriminatory practices and unequal access to and use of technology (United Nations Development Programme Human Development Report, 2016). The Report elaborates that 42\%of women worldwide did not have a bankaccount in 2014 and the proportion waseven higher in developing countries (50\%). More so, in the 22 countries covered by the Global Entrepreneurship and Development Index, married women did not enjoy the same legalrights as married men, and in 8 countrieswomen did not 
enjoy the same legal access toproperty as men (United Nations Development Programme Human Development Report, 2016). These statistics are typical examples of how socio-economic and legal barriers may block female potential entrepreneurs from engaging in entrepreneurship or psychologically processing their entrepreneurial propensity.

In the African context, the limited freedom of women to conceptualise and engage in entrepreneurship manifests in the high gender inequity in SMME ownership partly due to constraining employment opportunities and slow integration of small-sized enterprises into the formal economy (United Nations Development Programme African Human Development Report, 2016). A World Bank study (2015) found that among the 40 sub-Saharan countries, only eight demonstrated gender balance in SMME ownership or a situation favourable to women.By the same token, a survey conducted on new entrepreneurial start-ups in the technology sector (including software development and services, e-commerce and online services, gaming, and telecoms and mobile services) in the Arab states in 2013 revealed that $75 \%$ of these companies had male founders while only $23 \%$ of entrepreneurs were female (Wyne, 2014). This gender inequity in ownership, itself a consequence of multiple socio-economic (e.g. limited access to loans for female potential entrepreneurs), legal (e.g. demands for collateral security which most female entrepreneurs may not have) and political constraints set a bad precedence for entrepreneurial propensity and may project negative connotations about women's engagement in and willingness to create new ventures. The logical consideration of individuals' values and institutional processes in this theory demonstrates the complementarities of personal and macro factors in business opportunity recognition and business start-up, the same way individual factors (e.g. one's gender) may shape the perceptions of entrepreneurial barriers, which mayundermine one's willingness to pursue new venture creation.

\section{Literature Review}

Gender and economic development: The question of whether gender parity improves economic activity remains a contentious issue. Literature reveals that many arguments for equal participation of women and man in economic activity have been values-driven rather than function-based (Chant \& Sweetman, 2012; Roberts \& Soederberg, 2012; Bergeron \& Healy, 2013). Generally, there is a perception that encouraging women to participate in economic activity brings gender diversity in the economy, which is an ideal quality to society. This is particularly in view of the concentration of women in labour intensive and less capital and technology intensive industries. For instance, Wyne's study (2014) reported that the low female representation in technology oriented start-ups (e.g. software development and services, e-commerce and online services, gaming, and telecoms and mobile services) pointed to the need for more inclusive educational programmes and gender diversity to expand the pool of innovation. By the same token, Brooks, Huang, Kearney, and Murray's (2014) study conducted in the United States affirms that male and female-led ventures tend to focus on differenttypes of market opportunities with differing levels of growth potential. They elaborate that male entrepreneurs tended to pursue venturesacross a broad spectrum of industries, whereas female entrepreneurspredominantly pursued ventures that focus on thefemale consumer, such as fashion, cosmetics, and cooking.This research demonstrates that distinct gender gaps persist in men and women's economic contribution to national economies within countries.

There is growing consensus thatsmart economics encourage gender parity in economic participation, which doubly benefits both women and the country at large through invigorated economic output, better-quality development for the future generations, and augmented gender diversity in institutions and policies (Harcourt, 2012; Ravenga and Shetty, 2012a,b).The inverse is also true-gender inequity accelerates unbalanced growth, uneven development and results in net financial outflows.The African Human Development Report (2016) reports that the pervasive gender gap in economic and entrepreneurship activities is constrainingAfrica's achievement of its full economicpotential - averaging a loss of about \$95 billion annuallysince 2010 in Sub-Saharan Africa alone.The Global Gender Gap Report (2013)illustrates that the economic disempowerment of women through failure to invest in their education costed the Asia and Pacific region US $\$ 16$ billion to US $\$ 30$ billion annually (Bekhouche, Hausmann, Tyson, \& Zahidi 2013). Apart from that, the Global Gender Gap Report (2014) proclaims that the narrowing of the male and female participation gap in the labour force accrues the USA and European Union approximately $9 \%$ and 13\% of GDP per annumrespectively (cited in World Economic Forum, 2015).The picture cast in the aforementioned 
studies is that although much progress has been made in empowering women in the economic spheres of life, they still lag behind men.

Gender and entrepreneurship: Personal factors such as individual traits, psychological, behavioural and motivational influences (Langowitz \& Minniti, 2007; Urban, 2010; Farrington, Gray and Sharp, 2012), socioeconomic and institutional factors are often highlighted as the explanations for gender based differences in perceptions of entrepreneurial opportunities and barriers (Pérez-Pérez \& Avilés-Hernández, 2015). Akehursta, Simarrob and Mas-Tur (2012) cite psychological factors such as personal drive (to have control over one's destiny, make personal decisions and achieve the most out of oneself) and perceptual aspects (the ability to identify entrepreneurial opportunities in the business environment, risk-perception, perceived entrepreneurial capabilities, tolerance for ambiguity and uncertainty) as key influences of the ability of women to engage in entrepreneurship.

Psychological factors include male and female students' perceived self-efficacy and locus ofcontrol to create and operate businesses successfully. For Ajzen (1991), the psychological aspects relate to "how hard people are willing to try and how much effort they are planning to exert, in order to perform the behavior" (Ajzen, 1991, p. 181)such as new venture creation.If the psychological aspects capture the perceived ease of creating a business in view of the socio-economic context and socially ascribed gender roles and responsibilities, then females and males may be differentially positioned with regard to their perceptions of establishing business businesses. The Human Development Report (2015) highlights that comparingunpaid care work (e.g. housework, such as preparing meals for the family, cleaning the house and gathering water and fuel, as well as work caring for children, older people and family members who are sick) and paid work there continues to be pronounced imbalances across genders, reflecting local values, social traditions and historical gender roles in Africa. In view of the intermingling of psychological beliefs and social construction of gender roles, entrepreneurial barriers and opportunities may be conceived differently by female and male students.

Behavioural intentions are often proposed as a means of explaining why some individuals embark on entrepreneurial activity and others do not (Ariff, Bidin, Sharif \& Ahmad, 2010; Engle et al., 2010; Farrington, Gray and Sharp, 2012; Fretschner, 2014). For instance, the Theory of Planned Behaviour is one of the popular theories for explaining entrepreneurial intentions and decisions to engage in and reluctance to engage in entrepreneurship behaviour (Ajzen, 1991; Lortie, and Castogiovanni, 2015; Tsordia and Papadimitriou, 2015). According to this theory, a person's attitude towards a behavior, subjective norm, and perceived behavioural control are significant factors that determine his intentions (Ajzen, 1991) to engage in entrepreneurship. Attitude towards behaviour is perceived as "the degree to which a person has a favourable or unfavourable evaluation or appraisal of the behavior in question" (Ajzen, 2002, p. 5) such as engagement entrepreneurial behaviour. If a student conceive participation in new venture creation to be ideal to their situated context and given circumstances (e.g. resource base, general environment), she would be more inclined to engage in such behaviour than if evaluated the contexts and circumstances to be negative.

Farrington, Gray and Sharp's (2012) study reported different motivational factors for female and male engagement in entrepreneurship. While female students expressed the needs for increased flexibility and autonomy as their main motivations for intending to engage in self-employment, male studentsperceived selfemployment to provide them with more time to meet business responsibilities. Farington et al.'s (2012) study reported that due to household and child-rearing responsibilities which still dominate most women's social life, female business owners perceived having their own business to allow them autonomy, flexibility to vary activities and freedom to regulate working hours more than males did. To the contrary, men were less likely to see themselves as being responsible for household and child-rearing duties but were more likely to see their role as providing for their families. This created the perception that having their own business would require more work and less flexibility in order to meet these commitments. Again, women's family roles such as manning the household mean that they have to share the time available to them between parenting and engaging in economic activity (Nani, 2011). Thus, time constraints restrict women to less time consuming informal sector entrepreneurial activities rather than starting a formal business. More so, female roles such as being key providers for families entice them to seek to secure consistent and reliable sources of income (Elborgh-Woytek et al., 2013). Hence, they may shun risky and growth-oriented ventures and focus on those simple projects that guarantee extra income to the family. 
Social desirability and viability: At the socio-economic level, issues of social desirability and viability of entrepreneurial ventures created by men and those incubated by women is brought into sharp focus. A study conducted by Dabic, Daim, Bayraktaroglu, Novak and Basic (2012) study on gender differences in university students' attitudes towards entrepreneurship revealed that compared to males, female students are less willing to start their own businesses. They identified significant gender differences in terms of perceived feasibility and perceiveddesirability especially that although they feel more supported by their families, females are less self-confident,tenser, and reluctant to engage in entrepreneurship compared to males. In terms of entrepreneurial intention, thereare fewer gender differences among students; although differences relating to self-confidence and family support still exists. Sánchez-Escobedo, Díaz-Casero, HernándezMogollón and Postigo-Jiménez (2011) examined perceptions of the public image of the entrepreneur, along with the desirability, viability and intentionality of students towards creating their own business to establish possible gender differences in the perceptions and attitudes of university students towards entrepreneurship. Data analysis using bivariate and multivariate techniques revealed that gender plays a significant role in how the figure of the entrepreneur is perceived and in the intention to generate new businesses.The theory of planned behaviour emphasises the importance of subjective norm, that is, significant and knowledgeable others (educators, business consultants, friends and family) in shaping students' uptake of entrepreneurial behaviour (see Ajzen, 2001; Solesvik, Westhead, Kolvereid \& Matlay, 2012; Tsordia \& Papadimitriou, 2015). Female and male students may be differentially positioned in their subjective norms' influence on therecognition of entrepreneurial opportunities and barriers. The socially constructed gender roles and societal expectations of men and women can position them differently in their motivations for identifying entrepreneurial opportunities' or barriers and acting on them. Daim, Marina Dabic and Elvan Bayraktaroglu (2016)'s study, which tested student gender against entrepreneurial desirability and feasibility in 10 countries, revealed significant differences between genders and countries in their perceptions of desirability and feasibility of entrepreneurial behavior.

Gender differences are also noticeable at the motivation to engage in entrepreneurship as well at the qualitative non-economic entrepreneurial outcomes. A study conducted by Herrington and Kelley (2012) on the factors driving sub-Saharan African entrepreneurship revealed that women engaged in entrepreneurship to raise income to look after their families, pay for their children's schooling, to achieve financial autonomy and to improve their status in society. As such, women tend to engage in necessity-driven entrepreneurship compared to opportunity-driven entrepreneurship. With reference to the relationship between gender and entrepreneurship outcomes, the research evidence is inconclusive. Bosma et al. (2013) study on the growth expectations of male and female entrepreneurs in both factor and innovation driven economies revealed that females had relatively lower growth expectations as compared to their male counter parts. Meek and Sullivan (2013) observed that while many studies find significant differences between men and women in economic outcomes of entrepreneurship, explanations for these differences vary widely. Their study reports that male and female entrepreneursdiffered with regard to several relationship-oriented, non-economic entrepreneurial outcomes, while showing no differences in regards to traditional economic outcomes.

Gender and entrepreneurial opportunity and barriers: The intricate connection between gender and entrepreneurship can be explored from the personal, institutional, regulatory and societal perspectives. At the personal level, psychological and cognitive aspects, concrete motivation (desire for progress and autonomy, need for achievement and fulfilment etc.) and individual subjective perception (risk tolerance, self-confidence, recognition of business opportunity etc.) are conceived to be instrumental in shaping student decisions to engage in or desist from entrepreneurship (Pérez-Pérez and Avilés-Hernández, 2016). The institutional imperatives tend to consider the role of the family in supporting and socialising women into entrepreneurial behaviour. The family can foster or hinder the females' willingness to undertake new ventures through providing or withholding the economic resources to start a business (Pérez-Pérez and Avilés-Hernández, 2016). Research evidence suggests that women experience more complexity in their career choices in view of work value-time than men due to the need to balance their work and family roles (DeTienne \& Chandler, 2007). However, family can also serve as anagent of socialisation that can stimulate women's entrepreneurial spirit, activating their keenness to continue with the existing family business or daring to create their own (Pérez-Pérez \& Avilés-Hernández, 2016). 
Regulatory factors focus on administrative and legal frameworks, processes and procedures that facilitate and hinder the pursuit of new venture creation. The gender mainstreaming laws in Zimbabwe recognise the need for and provide proactive interventions for increasing female participation in economic activity, though clear gender-sensitive policies in the funding of emerging businesses are yet to emerge. This scenario can be contrasted with the Vietnamese case. A Gender Equality Law passed by the National Assembly of Vietnam in 2006 makes several provisions that make female participation in entrepreneurship a profitable activity. The Vietnam Women Entrepreneurs Council's (VWEC) (2007) highlights that Article 12 of this law specifies that "women and men are equal in establishing enterprises, conducting production and business activities, managing enterprises as well as in accessing information, capital, markets and human resources". The same article also provides "measures to promote gender equality in the economy" stipulating that (a) enterprises employing many female workers shall be given preferential treatment in terms of finance and taxation in accordance withlegal regulations (VWEC, 2007). The Vietnam case parallels the South African experience. Although the South African constitution is considered as one of the most progressive legal documents in the world, there no hard evidence for public funding institutions' preferential treatment of women in extending credit or gender sensitive taxation for female-owned and female-operated businesses.

Some studies also consider the socio-economic characteristics of women (age, education, income or finance, professional experience, social norms) as individual factors influencing female entrepreneurship (Pine, Lerner \& Schwartz, 2010; Pérez-Pérez \& Avilés-Hernández, 2016; Rubio-Bañón\& Esteban-Lloret, 2016). Due to high demands for a consistent income and pressing household commitments, Bosma et al. (2009) acknowledge that the percentage of women entrepreneurs is higher in countries where the general income per capita is small and where women have no other option for making a living (such as Angola, Bolivia and Peru) and lower in countries where the general income per capita is high (such as Israel, Germany and the UK) (Bosma et al., 2009). Another barrier to women advancement in entrepreneurship is lack of adequate funding. Pine, Lerner and Schwartz (2010) highlight the disconcerting fact that a large percentage of women's businessesare very small and not part of the formal economy, factors which explain why they tend toreceive less financial support from public institutions. More so, women and men are differentially positioned in terms of access to credit financing. Godwin et al. (2006) argue that women are discriminated when trying to access resources needed for their business. The fact that more women than males are in small, informal, livelihoodoriented entrepreneurship (LOEs) as compared to growth-oriented entrepreneurship often further compound the problem. A study on the women's entrepreneurship development in Vietnam highlights that more men (80\%) than women (72\%) are in growth-oriented entrepreneurship (GOE) (The Vietnam Women Entrepreneurs Council's (VWEC), 2007). This gender gap means that more men stand a better chance of securing funding as they concentrate on businesses founded on a solid grasp of economic opportunities than LOEs, which struggle to secure funding due to their informal or semi-formal orientation.

The concentration of most women in non-technical fields of education training (e.g. social sciences, humanities, arts) and their limited visibility in the commercial (business, entrepreneurship) and STEM disciplines constrain women's capacity to function in the entrepreneurship field due the highly technical nature of new venture creation. The lack of technical skills tends to prevent them from entering and sustaining businesses in technical sectors (Pine, Lerner \& Schwartz 2010) and consequently, women have managed to penetrate the entrepreneurial arena but have failed to realise entrepreneurial success (Glover, 2002). Regrettably, most women predominantly attain the stages of qualifying or obtaining the relevant skills and obtaining entry or setting up a business but fail to persist and finally advance entrepreneurially (Pines et al., 2010). Even when entrepreneurship education is provided to prop the germane entrepreneurial skills of both gender, research seems to suggest that significant differences are noticeable across different gender. For instance, Shinnar, Hsu, and Powell's (2014) investigation of the influence of entrepreneurship education in strengthening entrepreneurial self-efficacy (ESE) and entrepreneurial intentions (EI) revealed that while ESE increased for both males and females, this increase was statistically significant only for the male students.

Social norms and gender stereotypes also serve as strong barriers to women entrepreneurship. The Theory of Social Role demonstrates how gender stereotypes conspire with social customs that define appropriate behaviour for women and men to project the male group as more inclined to have higher domain or achievement attitudes, while women are reduced to care behaviours and docility (Eagley, 1987; RubioBañón\& Esteban-Lloret, 2016). These social constructions of gender roles position men as ideal candidates 
for entrepreneurial activity while women's role are pushed to the periphery and restricted to the homestead. Therefore, the male group is configured as the ideal to start and run businesses (Bird \& Brush, 2002) and women are often conceived to provide best models of entrepreneurship propensity exclusively. Usually, female entrepreneurship is stereotyped with features that are incompatible with those observed in entrepreneurs who have achieved success in their business activities (Rubio-Bañón\& Esteban-Lloret, 2016).

\section{Methodology}

Research design: The objective of this study was to establish if any statistically significant differences in the perception of entrepreneurship barriers existed amongst students of different gender. The study employed a quantitative descriptive research design to accomplish this goal. According to Saunders et al. (2009), such a design requires that the researcher adopts a detached approach involving observation and measurement of variables as they exist without contamination of the data through direct, intensive interaction with respondents. Thus, the study was guided by the positivist paradigm that assumes that research must always employ scientific procedures, which are confined to what is observable and measurable. A positivist approach and descriptive design cohered with this study' intention to describe nature of the relationships between gender variable and entrepreneurial variable at a particular point. These approaches were also consistent with this study's commitment to generalisethe findings to the study population. More so, the outcomes from a quantitative study can be statistically verified for their reliability and significance.

Data collection: Data was collected using a self-completion questionnaire made up of close ended question items expressive of the following variables; entrepreneurship support, regulatory, personal, financial and socio-cultural barriers.The co-authoradministered the questionnaire to the respondents during lectures in early March 2016 over a one week period. Respondents were randomly selected from a sampling frame created using class name lists. Consistent with the ethics regulating academic inquiry into human subjects, students were apprised of the purpose of the study, their anonymity, voluntary participation in the study. All the sampled students expressed interest to participate in the study.

Respondents: Vocational education students doing an introductory course in entrepreneurship at a polytechnic in Zimbabwe were targeted for the study. These came from various academic faculties namely, Humanities, Applied Sciences, Creative Arts, Business and Engineering. The target population comprised almost 500 students from whom 365 were randomly sampled. Of these 365 respondents, a total of 169 respondents successfully completed and returned the questionnaire.

The validity and reliability research instrument: Validity refers to whether a research tool measures what it is actually intended to measure (Cooper \& Schindler, 2011). In other words, it ascertains the truthfulness of the results emanating from data which was gathered using a particular research instrument. On the other hand, reliability relates to the ability of a research instrument to generate consistent results when applied to the same target population at different times (Bryman \& Bell, 2011). Thus, a high level of reliability and validity of a research instrument enhances the quality of a research study.For the current study, the theoretical variableswereevaluated using self-rated, item measuring scales designed by the researchers on the basis of the literature they reviewed. The responses to the items were made on a 5-point Likert scale.

The exploratory factor analysis and Cronbach's alpha testwere conducted to assess the validity and reliability of the instrument respectively (see Tables 1 and 2). A principal component analysis (PCA) was conducted on the initial 43 items measuring barriers to entrepreneurship, with orthogonal rotation (Varimax). The preliminary test results revealed evidence of substantial factor cross-loading. Consequently, the items which were cross-loading were removed, leaving 29 items on questionnaire. A second round of PCA was then conducted on the revised instrument. The Kaiser-Meyer-Olkin measure verified the sampling adequacy for the analysis, $\mathrm{KMO}=0.76$, which is above the acceptable limit of 0.5 (Field, 2009). Bartlett's test of sphericity $\chi^{2}(253)=5504.564, p<.000$, indicated that correlations between items were sufficiently large for principal component analysis. An initial analysis was run to obtain eigenvalues for each component in the data. Five components had eigenvalues over Kaiser's criterion of 1 and in combination explained $66.861 \%$ of the variance. On the basis of Kaiser's criterion, five components were then retained. Table 1 shows the factor loadings after rotation. The items that cluster on the same components suggest that component 1 represents 


\section{Journal of Economics and Behavioral Studies (ISSN: 2220-6140)}

Vol. 8, No. 6, pp. 94-113, December 2016

a perception of financial barriers, component 2 social and cultural barriers, component 3 a perception of personal barriers, component 4 a perception of regulatory barriers and component 5 a perception of entrepreneurship support barriers. The preceding results confirm convergence validity of the measures in the questionnaire.

\section{Table 1: Rotated component matrix}

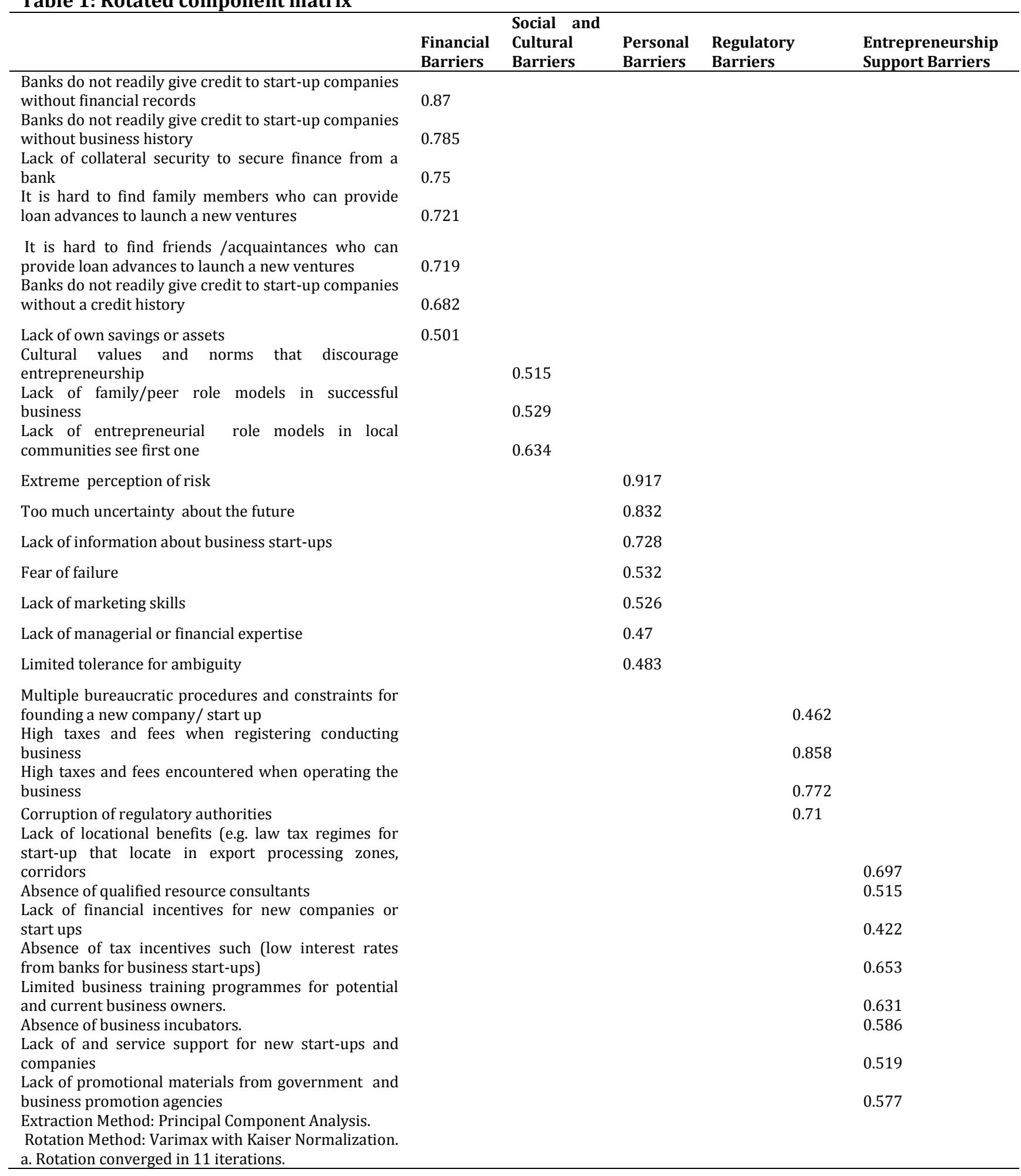




\section{Journal of Economics and Behavioral Studies (ISSN: 2220-6140)}

Vol. 8, No. 6, pp. 94-113, December 2016

The researchers conducted a Cronbach's alpha tests on the items that loaded under the five factors which were identified. The results are shown in Table 2.

Table 2: Reliability analysis

\begin{tabular}{|c|c|c|}
\hline Construct & $\begin{array}{l}\text { Number of } \\
\text { items }\end{array}$ & Cronbach'sapha \\
\hline Perception of financial barriers & 7 & 0.814 \\
\hline Perception of social and cultural barriers & 3 & 0.774 \\
\hline Perception of personal barriers & 7 & 0.783 \\
\hline Perception of regulatory barriers & 4 & 0.734 \\
\hline Perception of entrepreneurship support barriers & 8 & 0.782 \\
\hline
\end{tabular}

The results show a satisfactory level of reliability, with each construct having alpha coefficients of the minimum accepted level of 0.7 (George \& Mallery, 2016).

\section{Results}

Profile of respondents: The results are presented starting with descriptive statistics followed by the inferential statistics. Table 3 illustrates the profile of the respondents by gender, age, marital status and their respective fields of study. The results highlight that a majority of respondents were female (58.6\%) while the remainder were male. Also, slightly more than half (50.3\%) of the respondents were in the 20 to 30 years age category, followed by those under the age of 21 years (37.3\%) and lastly the 31 to 40 years (12.4\%) group respectively. In addition, $83.4 \%$ of the respondents were not married while only $16.6 \%$ were married. A majority (53.8\%) of the respondents came from the Engineering division, while Applied Sciences and Business comprised $16.6 \%$ and $20.7 \%$ of respondents respectively. The Creative Arts division contributed only $4.1 \%$.

Table 3: Profile of respondents

\begin{tabular}{lll}
\hline & N & \% \\
\hline Gender & 70 & 41.4 \\
Male & 99 & 58.6 \\
Female & 169 & 100 \\
Total & & \\
Age groups & 63 & 37.3 \\
Under 21 years & 85 & 50.3 \\
20 to 30 years & 21 & 12.4 \\
31 to 40 years & 169 & 100 \\
Total & & \\
Marital Status & 141 & 83.4 \\
Never married & 28 & 16.6 \\
Married & 169 & 100 \\
Total & & \\
Field of Study & 28 & 16.6 \\
Applied sciences & 35 & 20.7 \\
Business & 7 & 4.1 \\
Creative arts & 99 & 58.6 \\
Engineering & 169 & 100 \\
Total & &
\end{tabular}


Summary statistics for numeric variables: Prior to conducting inferential statistical tests, the composite scores for each construct measured were deduced and descriptive statistics compiled (see Table 4). The observations for total entrepreneurship support barriers ranged from 16.00 to 33.00, with an average of $26.38(S D=4.64)$. The observations for total regulatory barriers ranged from 10.00 to 25.00 , with an average of $19.62(S D=3.91)$. The observations for total personal barriers ranged from 9.00 to 39.00 , with an average of 24.29 ( $S D=7.57)$. The observations for total financial barriers ranged from 17.00 to 40.00 , with an average of $30.88(S D=6.44)$. The observations for total socialcultural barriers ranged from 10.00 to 45.00 , with an average of $30.08(S D=7.81)$. The general pattern of data suggests high means relative to maximum scores for perception of entrepreneurship barriers.

Table 4: Means table for numeric variables

\begin{tabular}{llllll}
\hline Variable & M & SD & n & Min & max \\
\hline Total entrepreneurship support barriers & 26.38 & 4.64 & 169.00 & 16.00 & 33.00 \\
Total regulatory barriers & 19.62 & 3.91 & 169.00 & 10.00 & 25.00 \\
Total personal barriers & 24.29 & 7.57 & 169.00 & 9.00 & 39.00 \\
Total financial barriers & 30.88 & 6.44 & 169.00 & 17.00 & 40.00 \\
Total social cultural barriers & 30.08 & 7.81 & 169.00 & 10.00 & 45.00 \\
\hline
\end{tabular}

Inferential statistics: To generate answers to the research questions, the researchers sought to determine if the means for the composite scores for dependent variables were significantly different across the gender categories. This can be done using either a parametric or non-parametric test depending on the normality of the data under study. Parametric techniques are suitable for data which is normally distributed. In contrast, non-parametric techniques are appropriate for data which is not normally distributed. The Shapiro-Wilk test was conducted to determine whether the composite scores for perception of financial barriers, perception of social and cultural barriers, perception of personal barriers, perception of regulatory barriers and perception of entrepreneurship support barriers could have been produced by a normal distribution. The results of the test, which are illustrated in Table 5, were statistically significant for most of the constructs except one. This suggests that the composite scores are unlikely to have been produced by a normal distribution, thus normality cannot be assumed. Resultantly, the Mann-Whitney U test which is a non-parametric technique used to determine if there is a significant difference between two groups (e.g., men versus women) on a scale level dependent variable was deemed appropriate for the current study. The test is an alternative to the independent samples t-test and does not share the independent samples t-test's distributional assumptions.

Table 5: Shapiro-Wilk $W$ test for normal data

\begin{tabular}{|c|c|c|c|c|c|}
\hline Variable & Obs & $\mathbf{W}$ & $\mathbf{V}$ & & Prob $>\mathbf{z}$ \\
\hline Perceived entrepreneurship support barriers & 169 & 0.95586 & 5.661 & 3.953 & 0.00004 \\
\hline Perceive regulatory barriers & 169 & 0.95476 & 5.802 & 4.010 & 0.00003 \\
\hline Perceived personal barriers & 169 & 0.99105 & 1.148 & 0.315 & 0.37625 \\
\hline Perceived financial barriers & 169 & 0.95182 & 6.180 & 4.153 & 0.00002 \\
\hline Total social and cultural barriers & 169 & 0.96010 & 5.117 & 3.723 & 0.0001 \\
\hline
\end{tabular}

Mann-Whitney $U$ test fordifferences in perception of entrepreneurship support barriers: A MannWhitney two-sample rank-sum test was conducted to examine whether there were significant differences in perception of entrepreneurship support barrier between the categories of gender. There were 70 observations in group 1 (males) and 99 observations in group 2 (females). The results of the Mann-Whitney $U$ Test were not significant, $\mathrm{U}=3944.5, z=-1.66, p=.096$. The mean rank for group 1 was 91.85 and the mean rank for group 2 was 79.25. This suggests that the distribution of perception of entrepreneurship support barriers for group 1(males) is not significantly different from the distribution of perception of entrepreneurship support barriers for group 2(females). Table 6 presents the results of the Mann-Whitney U Test. 
Table 6: Mann-Whitney $U$ test for perception of total entrepreneurship support barriers by gender

\begin{tabular}{llllll}
\hline & Males & Females & & \\
Variable & Mean Rank & Mean Rank & U & $\boldsymbol{Z}$ & $\boldsymbol{P}$ \\
\hline Total entrepreneurship support & 91.85 & 79.25 & 3944.5 & -1.66 & .096 \\
\hline
\end{tabular}

Mann-Whitney $U$ test for differences in the perception of total regulatory barriers to entrepreneurship: A Mann-Whitney two-sample rank-sum test was conducted to examine whether there were significant differences in the perception oftotal regulatory barriers to entrepreneurship between the classes of gender. There were 70 observations in the males group and 99 observations in the females group. The results of the Mann-Whitney $\mathrm{U}$ Test were not significant, $\mathrm{U}=3773, z=-1.11, p=.265$. The mean rank for males was 89.40 and the mean rank for females was 81.00. This suggests that the distribution of totalregulatorybarriers for males is not significantly different from the distribution of totalregulatorybarriers for females. Table 7 presents the results of the Mann-Whitney U Test.

Table 7: Mann-Whitney U test for totalregulatorybarriers by gender

\begin{tabular}{|c|c|c|c|c|c|}
\hline & Males & Females & & & \\
\hline Variable & Mean Rank & Mean Rank & U & $z$ & $p$ \\
\hline TotalRegulatoryBarriers & 89.40 & 81.00 & 3773 & -1.11 & .265 \\
\hline
\end{tabular}

Mann-Whitney $\mathbf{U}$ test for differences in perception of total personal barriers: A Mann-Whitney twosample rank-sum test was also conducted to examine whether there were significant differences in totalpersonalbarriers between the levels of gender. There were 70 observations in group 1(males) and 99 observations in group 2(females). The results of the Mann-Whitney U Test were significant, $U=2254, z=-$ $3.79, p<.001$. The mean rank for males was 67.70 and the mean rank for females was 96.50 . This suggests that the distribution of TotalPersonalBarriers for males is significantly different from the distribution of TotalPersonalBarriers for females. Table 8 presents the results of the Mann-Whitney U Test.

Table 8: Mann-Whitney $\mathrm{U}$ test for totalpersonalbarriers by gender

\begin{tabular}{|c|c|c|c|c|c|}
\hline & Males & Females & & & \\
\hline Variable & Mean Rank & Mean Rank & U & $Z$ & $P$ \\
\hline TotalPersonalBarriers & 67.70 & 96.50 & 2254 & -3.79 & $<.001$ \\
\hline
\end{tabular}

Mann-Whitney $\mathbf{U}$ test for differences in perception of total financial barriers: A Mann-Whitney twosample rank-sum test was conducted to examine whether there were significant differences in totalfinancialbarriers between the levels of gender. There were 70 observations in group 1(Males) and 99 observations in group 2(Females). The results of the Mann-Whitney U Test were significant, $U=4581.5, z=-$ $3.71, p<.001$. The mean rank for males was 100.95 and the mean rank for females was 72.75 . This suggests that the distribution of totalfinancialbarriers for males is significantly different from the distribution of totalfinancialbarriers for females. Table 9 presents the results of the Mann-Whitney U Test.

Table 9: Mann-Whitney U Test for TotalFinancialBarriers by Gender

\begin{tabular}{llllll}
\hline \multicolumn{7}{l}{ Males } & Females & & \\
\hline Variable & Mean Rank & Mean Rank & U & $Z$ & $P$ \\
TotalFinancialBarriers & 100.95 & 72.75 & 4581.5 & -3.71 & $<.001$ \\
\hline
\end{tabular}

Mann-Whitney $\mathbf{U}$ test for differences in perception of total social cultural barriers: A Mann-Whitney two-sample rank-sum test was conducted to examine whether there were significant differences in total social cultural barriers between the categories of gender. There were 70 observations in the males group and 99 observations in the females group. The results of the Mann-Whitney $U$ Test were not significant, $U=$ 2915.5, $z=-1.66, p=.097$. The mean rank for males was 77.15 and the mean rank for females was 89.75. This suggests that the distribution of total social cultural barriers for males is not significantly different from the distribution of total social cultural barriers for females. Table 10 presents the results of the Mann-Whitney U Test. 
Table 10: Mann-Whitney U Test for totalsocialculturalbarriers by gender

\begin{tabular}{llllll}
\hline & Males & Females & & & \\
\hline Variable & Mean Rank & Mean Rank & $\mathrm{U}$ & $z$ & $p$ \\
TotalSocial and CulturalBarriers & 77.15 & 89.75 & 2915.5 & -1.66 & .097 \\
\hline
\end{tabular}

Discussion: The aim of the study was to establish if there were any gender-driven differences in the perception of barriers to entrepreneurship amongst vocational education students. The findings from this study demonstrate mixed results with no clear pattern on the effect of gender differences on the perceptions of barriers to entrepreneurship activities by Zimbabwean vocational education students. From the first research question, it was hypothesised that they were statistically significant differences in the perception of entrepreneurship support barriers across the gender groups. The null hypothesis was supported since the $p$ value of 0.096 was larger than 0.05 , indicating non-significance at $5 \%$ level. Thus, it was concluded that they were no significant differences in perceived entrepreneurship barriers amongst female and male students at the same educational levels. If exclusion and inclusion encapsulate having, or not having, access to critical assets, services and resources (Room, 1995, Pines et al., 2010), then it can be argued that university entrepreneurial educators equally equipped both female and male students (i.e. prospective entrepreneurs) with inclusive entrepreneurial education, pre-requisite entrepreneurial capabilities and competencies to identify and recognise perceived entrepreneurial challenges. Theabsence of a significant genderdifferences in perceptions is somehow inconsistent with Powell and Eddlestone (2013) and Belwal, Tamiru and Singh's (2012) findings that females in developing countries felt that socio-economic interventions in their economies disproportionately favoured male entrepreneurship against male entrepreneurship.

The absence of significant differences in perceived entrepreneurship support barriers amongst female and male students, however, coheres with Nani (2011) and Zindiye et al. (2012) revelations on the prevalence of gender inclusive entrepreneurship support for emerging entrepreneurs in Zimbabwe. The development of a supportive regulatory and incentive environment is one such expression of entrepreneurial support. Zindiye et al. (2012) observe that the government of Zimbabwe has taken far-reaching measures to redress the hindrances to new venture creation and entrepreneurship. The measures include the institution of the Small Business Act, Business Formation and Licensing Procedure and the Reporting and Administrative Requirements, which are all intended to enhance the ease of registering and running of small informal business, render training and service support for new start-up companies in Zimbabwe. This is particularly important in view of Muchena's (2009) claim that most female-owned businesses in the country operate in the informal, low paying informal sector. More so, since necessity entrepreneurship dominates the Zimbabwean economic landscape, the lack of significant gender differences can also be attributed to the universal impact of "push factors" that may drive both genders to engage in entrepreneurship. The gender balance, therefore, can be attributed to the prevalence of necessity [driven] entrepreneurship among women in developing countries (Bosma et al., 2009; Pines et al., 2010). To the extent that the findings of the current study reflected a lack of difference in the perception of barriers to entrepreneurship, one may assume that perhaps policies to support entrepreneurship give equal importance to both genders. With reference to the status of women empowerment in Zimbabwe, Muchena (2009) cited the entrenchment of progressive gender equality and affirmative action in the national constitution and other policy interventions. 2007).

The second hypothesis postulated that there were significant differences on the perception of regulatory barriers entrepreneurship between male and female students. Again, the null hypothesis was supported as the $p$-value of 0.256 for the Mann-Whitney test was larger than 0.05 .The absence of significant gender-based differences in perceptions of regulatory barriers was not surprisinggiven that the Zimbabwean government created two ministries to deal with issues of gender equality and women empowerment in business. The Ministry of Women Affairs, Gender and Community Development deals with the acceleration of gender mainstreaming in different ministries and public departments, the advancement of women empowerment through SMME development and addresses issues of gender equality in business and professional occupations. The Ministry of Small and Medium Enterprise and Cooperative Development deals with the development of small businesses, finance and administration services in ways that advance gender mainstreaming in funding, resource mobilisation and technical advisory services to prospective and existing emerging entrepreneurs. Research evidence suggest that where policy and legal frameworks for gender 
mainstreaming in entrepreneurship exists, gender gaps in perceptions of business propensity and ultimately entrepreneurship tend to be breached (The Vietnam Women Entrepreneurs Council (VWEC), 2007).

The results of the Mann-Whitney test on whether they were significant differences on the perception of personal barriers to entrepreneurship suggest that the null hypothesis was rejected since the $p$-value for test was less than 0.05. Thus, significant differences existed across gender groups. The mean score of 96.50 for women exceeded that of men (67.70) and this finding is consistent with literature which has suggested that potential women entrepreneurs perceive more personal barriers to entrepreneurship than men (Mboko \& Smith-Hunter, 2009; Mboko \& Smith-Hunter, 2010; Chirisa, 2013).The barriers that often constrain women engagement in entrepreneurship range from their low socio-cultural status and constrained access to corporate and information networks (Rodríguez \& Santos, 2008; Pérez-Pérez and Avilés-Hernández, 2016), a lack of emotional and psychological support, credible role models and the necessary knowledge to promote female participation in entrepreneurship (Krueger and Brazeal, 1994, Dabic et al., 2012). Other barriers include challenges in reconciling family and business responsibilities (Moore \& Buttner, 1997; Brush, De Bruin, \& Welter, 2009) and limited education and training of women as entrepreneurs and entrepreneurship (Pineda, 2014). According to Chitsike (2000) personal barriers to entrepreneurship by women emanates from cultural norms and values, which generally condition women's minds to have self-doubt about their abilities to establish and run growth-oriented businesses successfully.

However, our findings were inconsistent with findings in conventional literature as they showed that male students perceived more financial barriers to entrepreneurship when compared to female students. Findings from some studies relating to barriers to women entrepreneurship in Zimbabwe suggest that women generally encounter more financial hindrances relative to men (Chitsike, 2000; Nyamanzwa et al., 2012; Nani, 2011; Gwakwa \& Chikukutu, 2015). A possible explanation for this discord may be the wide-reaching efforts undertaken by the Zimbabwean government to ensure equal access to economic resources and participation in entrepreneurial activities by both genders. For instance, since year 2000, the government has consistently had in place a dedicated Ministry of Women' Affairs, Gender and Community Development, which is responsible for ensuring gender parity in empowerment and developmental issues. At the same time, there exists a full Ministry of small and Medium Enterprises whose entrepreneurship promotion programmes have generally favoured youth and women as the previously disadvantaged members of the community (Nani, 2011; Zindiye et al., 2012; Gwakwa \& Chikukutu, 2015). The effectiveness of such efforts perhaps explains why females now perceive less financial barriers to entrepreneurship than men. The results for the Mann Whitney test for differences in perceptions of social and cultural barriers to entrepreneurship demonstrate that females had a higher mean score of 89.75 compare to the score of 77.15 for males. However, the distinction was no statistically significant at the $5 \%$ level as reflected by the p-value of 0.097 . In spite of the lack of statistical significance of the difference, the stronger perception of social and cultural hindrances are consistent with findings of some scholars that cultural norms are critical barriers to women's participation in political, social and economic activities (Chitsike, 2000; Gaidzanwa, 2004; Nani, 2011; Mazonde \& Carmichael, 2015).

\section{Theoretical and practical implications and Conclusion}

The current study was informed by the Shapero and Sokol (1982) entrepreneurial event model and the theory of Harper' entrepreneurial discovery. For Shapero and Sokol (1982), the existence of a significant event, such as a push or pull factor, which disrupts and changes the trajectory of an individual's life could explain one's decision to engage in entrepreneurship or their reluctance to do so. Push factors include job loss, job dissatisfaction and a salary cut or a demotion. Pull factors comprise the existence of a perceived rewarding market opportunity, need for independence and promulgation of support structures for new business start-ups, which actually encourage entrepreneurship (Ismail, Shamsudin \& Chowdhury, 2012; William \& Williams, 2014). In view of the excessive deflationary environment in Zimbabwe characterised by extensive joblessness in the formal sector, severe cuts in salaries in the civil service and the private sector, and the absence of job prospects may compel students of both gender to consider entrepreneurship. In the same vein, the existence of supportive policy structures and interventions in the Zimbabwean context may also be activating the spirit of entrepreneurship among students. The absence of significant statistical differences across gender with regard to the perceived entrepreneurship barriers suggests that even though 
entrepreneurial events (e.g. push factors) are supposed to trigger entrepreneurship, the wider recognition of entrepreneurial barriers by both gender could be an inhibitor entrepreneurship. It can be inferred that while trigger events may trigger entrepreneurial propensity, the reality is that the effective exploitation of an entrepreneurial event is a consequence of the perceived plausibility and perceived desirability of the entrepreneurial behavior. Research shows that the effect of the trigger event is subject to one's perception of the plausibility of entrepreneurial behaviour (Krueger et al., 2011; Ngugi \& Gakure, 2012).

While Haper's (2003) theory of entrepreneurial discovery emphasises the possession of self-control and selfefficacy as critical to the recognition to entrepreneurial opportunities, it can be inferred from the findings these qualities are insufficient for the pursuit of entrepreneurship if the macro-economic environment is not sufficiently supportive and ideal for SMMEs to thrive. The lack of statistically significant gender differences on student perceptions of entrepreneurial support point to the fact that both males and female students conceived lack of various support systems (finance, training, skills) as impediments to entrepreneurship, even though these students may have possessed self-control and self-efficacy required to engage in entrepreneurship.

The lack of statistically significant gender differences among both gender with regards to regulatory barriers, through surprising (as females were expected to have higher statistically significant perceptions), demonstrates the difficulty of conducting businesses in a highly regulated, economically distressed environment. While the theory of entrepreneurial discovery alludes to the fundamental importance of individual freedom from regulatory controls as a basis for entrepreneurial propensity (Harper, 2003; Elam, 2008), the recognition of regulatory barriers across gender points to how multiple regulatory and policy constraints may compromise the pursuit and practical application of entrepreneurial intentions. Consistent with Shapero's model, which suggests that entrepreneurial intentions are directly shaped by perceived feasibility and propensity to act (Shapero and Sokol, 1982; Dabic et al, 2012), it can be argued that the prevalence of entrepreneurial barriers can be inimical to the fostering of perceived feasibility of businesses and undermines prospective entrepreneurs' propensity to pursue business ventures.

The findings from the current study revealed that males and females only had different perceptions on the existence of financial and personal hindrances to entrepreneurship. Male respondents felt financial factors were a stronger impediment to them when compared to females. On the other hand, female respondents had significantly stronger perceptions of personal barriers to entrepreneurship when compared to males. The implications of these findings are as follows;

- The strong perceptions of financial barriers among males compared to females suggest that the targeting of females in financially inclusive interventions could be replicating financial prejudices and disadvantages for men. More gender inclusive financial interventions may need to provide differentiated financial services and offering for both men and women. The implication is that while gender inclusive policies need to target womencontinually, they should also be specialised financial offerings for men to ensure that they are not marginalised by good intention policies that advance women financial interests.

- Female respondents had significantly stronger perceptions of personal barriers to entrepreneurship when compared to males which were attributed to many factors. These perceptions of barriers were conceived to arise from women's competing family and business commitments, their perceived low socio-cultural status, constrained access to corporate and information networks, a lack of emotional and psychological support, credible role models and the necessary knowledge and limited education and training of women as entrepreneurs and entrepreneurship. The competing family responsibilities and low socio-cultural status of women implies that radical transformations in the configurations of power in the family and society should unfold through multiple interventions. These include theequalisation of decision making in the family, increasing supplementary sources of income for women, the need to increase gender based forums for exchange of financial information sources and financial networks among women, and the creation of group or community-based saving groups to reduce dependence on debt funding. Other interventions may include the provision of psycho-social support systems such as women entrepreneurship clubs to increase the self-efficacy and self-esteem of womenwith regard to entrepreneurship. 
- Although it is a positive step that a previously disadvantaged group (women) now perceives fewer barriers to entrepreneurship, it is also counter-productive to have men perceiving more hindrances because of the measures implemented to correct the previous imbalances. This is particularly significant in a context of high unemployment where entrepreneurship careers and self-employment are the conceived as the most significant panacea to the problem. The introduction of differentiated public and private systems of entrepreneurial training, financial management and resource mobilisation support systems targeting different groups would ensure more balance entrepreneurship growth intentions and expectations across both gender.

Finally, further research on barriers to students' entrepreneurship could investigate the effect of other demographic factors like age group, marital status and field of study on the perceptions of entrepreneurial barriers. Further studies should encompass diverse institutions of higher learning so as to corroborate the findings of this paper.

\section{References}

Ajzen, I. (1991). The theory of planned behavior. Organizational behavior and human decision processes, 50(2), 179-211.

Ajzen, I. (2002). Constructing a TPB questionnaire: conceptual and methodological considerations. Retrieved from 31 June 2016, from thttp://chuang.epage.au.edu.tw/ezfiles/168/1168/attach/20/pta_41176_7688352_57138.pdf

Ajzen, I. (2006). Behavioral interventions based on the theory of planned behavior. Retrieved from 31 June 2016 from: http://people.umass.edu/aizen/research.html.

Ariff, A. H. M., Bidin, Z., Sharif, Z. \& Ahmad, A. (2010). Predicting entrepreneurship intention among Malay University Accounting students in Malaysia. Unitar E-Journal, 6(1), 1-10.

Bandiera, O. \& Natraj, A. (2013). Does Gender Inequality Hinder Development and Economic Growth? Evidence and Policy Implications. The World Bank Research Observer, 28(1), 2-21.

Bardasi, E., Blackden, C. M. \& Guzman, J. C. (2007). Gender, Entrepreneurship, and Competitiveness. The Africa Competitiveness Report.

Barro, R. J. (2013). Education and economic growth. Annals of Economics and Finance, 14(2), 301-328.

Bekhouche, Y., Hausmann, R., Tyson, L. D. \& Zahidi, S. (2013). The Global Gender Gap Report 2013. Geneva Switzerland, World Economic Forum 2013.

Belwal, R., Tamiru, M. \& Singh, G. (2012). Microfinance and sustained economic improvement: Women small-scale entrepreneurs in Ethiopia. Journal of International Development, 24(S1), S84-S99.

Benard, M. C. \& Victor, K. R. (2013). SWOT analysis of growth of women entrepreneurs in Dar es Salaam. Academic Research International, 4(1), 50.

Benería, L., Berik, G. \& Floro, M. (2015). Gender, development and globalization: economics as if all people mattered. Routledge.

Bergeron, S. \& Healy, S. (2013). Beyond the Business Case: A Community Economics Approach to Gender, Development and Social Economy. In Draft paper prepared for the UNRISD Conference on Potential and Limits of Social and Solidarity Economy, Geneva (pp. 6-8).

Bird, B. \& Brush, C. (2002). A gendered perspective on organizational creation. Entrepreneurship theory and practice, 26(3), 41-66.

Bloom, D. E., Canning, D. \& Chan, K. (2006). Higher education and economic development in Africa (Vol. 102). Washington, DC: World Bank.

Bosma, N., Wennekers, S. \& Amorós, J. E. (2013). Global Entrepreneurship Monitor 2012 Global Report. Babson College, Babson Park, MA.

Brooks, A. W., Huang, L., Kearney, S. W. \& Murray, F. E. (2014). Investors prefer entrepreneurial ventures pitched by attractive men. Proceedings of the National Academy of Sciences, 111(12), 4427-4431.

Brush, C., De Bruin, A. \& Welter, F. (2009). A gender-aware framework for women's entrepreneurship. International Journal of Gender and Entrepreneurship, 1, 8-24.

Bryman, A. \& Bell, E. (2011). Business Research Methods. 3rd Edition, Oxford: Oxford University Press.

Chant, S. (2012). The disappearing of 'smart economics'? The World Development Report 2012 on Gender Equality: Some concerns about the preparatory process and the prospects for paradigm change. Global Social Policy, 12(2), 198-218. 
Chant, S. \& Sweetman, C. (2012). Fixing women or fixing the world? 'Smart economics', efficiency approaches, and gender equality in development. Gender\& Development, 20(3), 517-529.

Chirisa, I. (2013). Characterising Women in the Informal Sector and Their Struggles to Eke a Living Lessons from Ruwa, Zimbabwe.

Chitsike, C. (2000). Culture as a barrier to rural women's entrepreneurship: Experience from Zimbabwe. Gender \& Development, 8(1), 71-77.

Cooper, D. R. \& Schindler, P. S. (2011). Business Research Methods. 11 $1^{\text {th }}$ Edition. Boston: McGraw-Hill.

Dabale, W. P. \& Masese, T. (2014). The influence of entrepreneurship education on beliefs, attitudes and intentions: a cross-sectional study of Africa University graduates. European journal of Business and Social Sciences, 3(9), 1-13.

Dabic, M., Daim, T., Bayraktaroglu, E., Novak, I. \& Basic, M. (2012). Exploring gender differences in attitudes of university students towards entrepreneurship: an international survey. International Journal of Gender and Entrepreneurship, 4(3), 316-336.

Daim, T., Dabic, M. \& Bayraktaroglu, E. (2016). Students' entrepreneurial behavior: international and gender differences. Journal of Innovation and Entrepreneurship, 5(1), 1-22.

Daim, T., Dabic, M. \& Bayraktaroglu, E. (2016). Students' entrepreneurial behavior: international and gender differences. Journal of Innovation and Entrepreneurship, 5(1), 1-22.

DeTienne, D. R. \& Chandler, G. N. (2007). The role of gender in opportunity identification. Entrepreneurship theory and practice, 31(3), 365-386.

Eagly, A. (1987). Sex Differences in Social Behavior: A Social-role Interpretation. Hillsdale, NJ: Erlbaum.

Eagly, A. H. \& Wood, W. (1999). The origins of sex differences in human behavior: Evolved dispositions versus social roles. American psychologist, 54(6), 408.

Elam, A. (2008). Gender and entrepreneurship: A multi-level theory and analysis. Cheltenham, UK: Edward Elgar Publishing.

Elam, A. B. (2008). Gender and Entrepreneurship across 28 Countries: A multilevel analysis using GEM data. Unpublished dissertation: University of North Carolina.

Elborgh-Woytek, M. K., Newiak, M. M., Kochhar, M. K., Fabrizio, M. S., Kpodar, K., Wingender, M. P. \& Schwartz, M. G. (2013). Women, work, and the economy: Macroeconomic gains from gender equity. International Monetary Fund.

Engle, R. L., Dimitriadi, N., Gavidia, J. V., Schlaegel, C., Delanoe, S., Alvarado, I., He, X., Buame, S. \& Wolff, B. (2010). Entrepreneurial intent: A twelve-country evaluation of Ajzen's model of planned behavior. International Journal of Entrepreneurial Behavior \& Research, 16(1), 35-57.

Farrington, S., Gray, B. \& Sharp, G. (2012). The influence of gender and ethnicity on the perceptions of an Entrepreneurial career in the South African context. The Southern African Journal of Entrepreneurship and Small Business Management, 5(1), 1-23.

Farrington, S., Gray, B. \& Sharp, G. (2012). The influence of gender and ethnicity on the perceptions of an Entrepreneurial career in the South African context. The Southern African Journal of Entrepreneurship and Small Business Management, 5(1), 1-23.

Fitzsimmons, J. R. \& Douglas, E. J. (2011). Interaction between feasibility and desirability in the formation of entrepreneurial intentions. Journal of Business Venturing, 26(4), 431-440.

Fretschner, M. (2014). Ajzen's theory of planned behavior in entrepreneurship education research. In becoming an entrepreneur (pp. 249-277). Rotterdam: SensePublishers.

Gaidzanwa, R. (2004). Gender, Women and Electoral Politics in Zimbabwe. Research Report No. 8. Johannesburg: EISA.

George, D. \& Mallery, P. (2016). SPSS for Windows step by step: a simple guide and reference (14 $4^{\text {th }}$ ed.). Boston, MA: Allyn and Bacon.

Glover, J. (2002). Women and scientific employment - current perspectives. New Research on Women, Science and Higher Education: Proceedings of the Conference. Athena Project, London.

Godwin, L. N., Stevens, C. E. \& Brenner, N. L. (2006). Forced to play by the rules? Theorizing how mixed-sex founding teams benefit women entrepreneurs in male-dominated contexts. Entrepreneurship Theory and Practice, 30(5), 623-642.

Gwakwa, M. \& Chikukutu, W. (2015). Barriers to Women Entrepreneurship: Zimbabwe's Experience-Pre and Post Independence Eras. The International Journal of Business \& Management, 3(11), 83-93.

Harcourt, W. (2012). Review Essay: Beyond 'Smart Economics': The World Bank 2012 Report on Gender and Equality. International Feminist Journal of Politics, 14(2), 307-312. 
Harper, D. A. (2003). Foundations of entrepreneurship and economic development. London: Routledge.

Herrington, M., Kew, J. \& Kew, P. 2010. Tracking entrepreneurship in South Africa: A GEM perspective. Cape Town: UCT Centre for Innovation and Entrepreneurship.

Ismail, H. C., Shamsudin, F. M. \& Chowdhury, M. S. (2012). An exploratory study of motivational factors on women entrepreneurship venturing in Malaysia. Business and Economic Research, 2(1), 1-13.

Kabeer, N. \& Natali, L. (2013). Gender Equality and Economic Growth: Is there a Win-Win? IDS Working Papers, 417, 1-58.

Kelley, D., Bosma, N. \& Amoros, J. E. (2010). Global entrepreneurship monitor 2010: Global report. Babson College, Universidad del Desarrollo and London Business School.

Klasen, S. (2002). Low schooling for girls, slower growth for all? Cross-country evidence on the effect of gender inequality in education on economic development. The World Bank Economic Review, 16(3), 345-373.

Krueger, N. F. \& Brazeal, D. V. (1994). Entrepreneurial potential and potential entrepreneurs. Entrepreneurship theory and practice, 18, 91-105.

Krueger, N., Hansen, D. J., Michl, T. \& Welsh, D. H. B. (2011). Thinking Sustainably: The Role of Intentions, Cognitions, and Emotions in Understanding New Domains of Entrepreneurship, in G.T. Lumpkin, Jerome A. Katz (ed.) Social and Sustainable Entrepreneurship (Advances in Entrepreneurship, Firm Emergence and Growth, ( pp.275 - 309), Volume 13) London: Emerald Group Publishing Limited.

Langowitz, N. \& Minniti, M. (2007). The entrepreneurial propensity of women. Entrepreneurship theory and practice, 31(3), 341-364.

Lortie, J. \& Castogiovanni, G. (2015). The theory of planned behavior in entrepreneurship research: what we know and future directions. International Entrepreneurship and Management Journal, 11(4), 935-957.

Madichie, N. O., Hinson, R. E. \& Ibrahim, M. (2013). A reconceptualization of entrepreneurial orientation in an emerging market insurance company. Journal of African Business, 14(3), 202-214.

Makwakwa, 0. (2015). Women and the Solidarity Economy. Retrieved on 27 June 2016 from http://www.osisa.org/openspace/economic-justice/global/women-and-solidarity-economy.

Malach Pines, A., Lerner, M. \& Schwartz, D. (2010). Gender differences in entrepreneurship: equality, diversity and inclusion in times of global crisis. Equality, Diversity and Inclusion: An International Journal, 29(2), 186-198.

Manuere, F., Danha, K. \& Majoni, T. (2013). Entrepreneurship Attitudes and Knowledge : a survey of $4^{\text {th }}$ year university students. Interdisciplinary Journal of Contemporary research in Business, 4(9), 511-521.

Mazonde, N. B. \& Carmichael, T. (2015). September. Culture and Entrepreneurship: A Developing Country Perspective. In European Conference on Innovation and Entrepreneurship (p. 765). Academic Conferences International Limited.

Mboko, S. (2008). Women entrepreneurs in Zimbabwe-A Case study. Journal of Global and Local Dynamics in African Business and Development. International Academy of African Business Development (IAABD), (9), 308-312.

Meek, W. R. \& Sullivan, D. M. (2013). Gender differences in entrepreneurship: assessing perceptions of entrepreneurial outcomes among men and women entrepreneurs (summary). Frontiers of Entrepreneurship Research, 33(8), 5.

Moore, D. P. \& Buttner, E. H. (1997). Woman Entrepreneurs - Moving beyond the Glass Ceiling. Thousand Oaks, CA: Sage Publications.

Muchena, O. (2009). Statement by the Minister of Women Affairs, Gender and Community Development to the $53^{\text {rd }}$ Session of the Commission on the Status of Women, United Nations Headquarters, New York, 2 to 13 March 2009.

Nani, G. V. (2011). Challenges faced by urban Zimbabwean women entrepreneurs. Unpublished doctoral dissertation, University of the Free State.

Ndofirepi, T. M. (2016). Impact of technological creativity and entrepreneurship education on the entrepreneurship intention of students at particular tertiary institutions in South Africa and Zimbabwe.Unpublished doctoral thesis, Central University of Technology, Free State.

Ngugi, J. K., Gakure, R. W., Waithaka, S. M. \& Kiwara, A. N. (2012). Application of Shapero's model in explaining entrepreneurial intentions among university students in Kenya. International Journal of Business and Social Research, 2(4), 125-148. 
Nyamanzwa, T., Mapetere, D., Mavhiki, S. \& Dzingirai, C. (2012). Financial Management: Case Study of Gweru Women Entrepreneurs. International Journal of Business and Social Science, 3(18) [Special Issue September 2012], 99-106.

O'DriscollJr, G. \& Rizzo, M. (2015). Austrian economics rexamined: The economics of time and ignorance. Routledge: Abingdon, Oxon.

Pérez, C. P., Hernández, M. A. \& Pérez, J. L. M. (2015). Motivospor los que se estudiaIngléscomosegundalengua en España. laexperiencia del aprendizaje en lasescuelasoficiales de idiomas (EOI). RevistaLugares de Educação, 5(11), 183-210.

Pineda, J. A. (2014). Emprendimiento y género: el caso de la industria de la belleza en Bogotá. Sociedad y Economía, 26, 239-272

Powell, G. N. \& Eddleston, K. A. (2013). Linking family-to-business enrichment and support to entrepreneurial success: Do female and male entrepreneurs experience different outcomes? Journal of Business Venturing, 28(2), 261-280.

Rambe, P., Ndofirepi, T. M. \& Dzansi, D. Y. (2015). Influence of Entrepreneurial Education and Technological Creativity on Entrepreneurial Intentions of Students in Zimbabwe: A Theoretical Perspective. 10th European Conference on Innovation and Entrepreneurship, 18-19 September 2015, Genoa, Italy.

Rambe, P. \& Ndofirepi, T. M. (In press). Influence of small business ethics on buying decisions of customers: A case of indigenous owned fast-food outlets in Zimbabwe. Journal of Economics and Behavioural studies.

Razavi, S. (2012). World development report 2012: Gender equality and development-A commentary. Development and Change, 43(1), 423-437.

Revenga, A. \& Shetty, S. (2012). World Development Report on Gender Equality and Development. World Bank.

Revenga, A. \& Shetty, S. (2012a). Empowering Women Is Smart Economics-Closing gender gaps benefits countries as a whole, not just women and girls. Finance and Development-English Edition, 49(1), 40.

Roberts, A. \& Soederberg, S. (2012). Gender equality as smart economics? A critique of the 2012 World Development Report. Third World Quarterly, 33(5), 949-968.

Rodriguez, M. J. \& Santos, F. J. (2008). Women nascent entrepreneurs and social capital in the process of firm creation. International Entrepreneurship and Management Journal, 5(1), 45-64

Room, G. (1995). Beyond the Threshold: The Measurement and Analysis of Social Exclusion. Bristol: The Policy Press.

Rubio-Bañón, A. \& Esteban-Lloret, N. (2016). Cultural factors and gender role in female entrepreneurship. Suma de Negocios, 7(15), 9-17.

Rubio-Bañón, A. \& Esteban-Lloret, N. (2016). Cultural factors and gender role in female entrepreneurship. Suma de Negocios, 7(15), 9-17.

Sánchez, J. C. (2011). University training for entrepreneurial competencies: Its impact on intention of venture creation. International Entrepreneurship and Management Journal, 7(2), 239-254.

Shane, S. (2015). Are Men Better Entrepreneurs Than Women? That's the Perception. https://www.entrepreneur.com/article/246815 Retrieved 6 September 2016.

Shane, S., Dolmans, S. A., Jankowski, J., Reymen, I. M. \& Romme, A. G. L. (2015). Academic entrepreneurship: Which inventors do technology licensing officers prefer for spinoffs? The Journal of Technology Transfer, 40(2), 273-292.

Shapero, A. \& Sokol, L. (1982). The social dimensions of entrepreneurship, in Kent, C., Sexton, D. and Vesper, K. (Eds) The Encyclopaedia of Entrepreneurship, Prentice-Hall, Englewood Cliffs, NJ, 72-90.

Shinnar, R. S., Hsu, D. K. \& Powell, B. C. (2014). Self-efficacy, entrepreneurial intentions, and gender: Assessing the impact of entrepreneurship education longitudinally. The International Journal of Management Education, 12(3), 561-570.

Solesvik, M. Z., Westhead, P., Kolvereid, L. \& Matlay, H. (2012). Student intentions to become self-employed: the Ukrainian context. Journal of Small Business and Enterprise Development, 19(3), 441-460.

Thébaud, S. (2015). Status beliefs and the spirit of capitalism: Accounting for gender biases in entrepreneurship and innovation. Social Forces, 94(1), 61-86

Tsordia C. \& Papadimitriou, D. (2015). The Role of Theory of Planned Behavior on Entrepreneurial Intention of Greek Business Students. International Journal of Synergy and Research, 4(1), 23-37.

Tyagi, R. C. \& Siddiqui, T. (2016). Private Enterprise Development among Socially Deprived Section of Society: Special Reference with Women Entrepreneur in India. PARIPEX-Indian Journal of Research, 5(5). 
United Nations Development Programme. (2000). UN Millennium Project | About the MDGs. Retrieved 27 June 2016, from http://www.unmillenniumproject.org/goals/

United Nations Development Programme. (2016). Human Development Report 2015. Retrieved 20 October 2016, from http://hdr.undp.org/sites/default/files/2015_human_development_report.pdf.

United Nations Development Programme. (2016). Africa Human Development Report 2015. Retrieved 20 October 2016, from http://www.undp.org/content/undp/en/home/librarypage/hdr/2016-africahuman-development-report.html.

Urban, B. (2010). Frontiers in entrepreneurship. London: Springer.

Verheul, I., van Stel, A. \& Thurik, R. (2004). Explaining female entrepreneurship across 29 countries. Discussion papers on entrepreneurship, growth and public policy. Max-Planck Institute, pp 1-32.

Vietnam Women Entrepreneurs Council. (2007). Women's entrepreneurship development in Vietnam. Hanoi, Vietnam: International Labour Office.

Wayne, S. J. (2014). Women's Managerial Aspirations an Organizational Development Perspective. Journal of Management, 40(3), 703-730.

Webb, J. W., Bruton, G. D., Tihanyi, L. \& Ireland, R. D. (2013). Research on entrepreneurship in the informal economy: Framing a research agenda. Journal of Business Venturing, 28(5), 598-614.

Williams, C. C. (2013). Beyond the formal economy: evaluating the level of employment in informal sector enterprises in global perspective. Journal of Developmental Entrepreneurship, 18(04), 1350027.

Williams, C. C. \& Youssef, Y. (2013). Evaluating the gender variations in informal sector entrepreneurship: Some lessons from Brazil. Journal of Developmental Entrepreneurship, 18(01), 1350004.

Williams, N. \& Williams, C. C. (2014). Beyond necessity versus opportunity entrepreneurship: some lessons from English deprived urban neighbourhoods. International Entrepreneurship and Management Journal, 10(1), 23-40.

World Bank Group. (2015). Accessing Institutions. Washington, D.C. Retrieved 27 June 2016, from http://wbl.worldbank.org/data/exploretopics/accessinginstitutions

World Bank. (2002). Engendering Development. Retrieved 27 June 2016, from http://siteresources.worldbank.org/PGLP/Resources/Engendering_Development.pdf

World Economic Forum. (2015). The Global Gender Gap Report 2013. Retrieved on 27 June 2016 fromhttp://reports.weforum.org/global-gender-gap-report-2015/the-global-gender-gap-index2015/.

Zindiye, S., Chiliya, N. \& Masocha, R. (2012). The impact of Government and other Institutions' support on the Performance of Small and Medium Enterprises in the Manufacturing Sector in Harare, Zimbabwe. International Journal of Business Management and Economic Research, 3(6), 655-667. 